\title{
アメンボ類の生息環境保全を目的とした淡水湿地の 環境整備指針
}

\author{
On the Improvement of the Environmental Conditions of a Freshwater Wetland for the Conservation of \\ Water Striders Habitat
}

山尾あゆみ* 中尾史郎** 中島敦司***養父志乃夫** 山田宏之** Ayumi YAMAO, Shiro NAKAO, Atsushi NAKASHIMA, Shinobu YABU Hiroyuki YAMADA

\begin{abstract}
摘要 : 近畿地方の 70 か所の淡水湿地で中型アメンボ類 5 種を対象に, 生息種構成と, 湿地周辺の土 地利用, 水面上の樹冠被率, 草本植生の生育型と植被率, ならひに汀線構造との関係を調查した。ま た室内実験で，産卵基質選好性およひ産卵場所の水面に対する位置関係を調査した。その結果，コセ アカアメンボとヤスマッアメンボの生息は, 湿地周辺の樹林地率, 水面上の樹冠被率や汀線部周辺の 土砂域の面積と, ナミアメンボ, ヒメアメンボおよびハネナシアメンボの生息は, 水面上の樹冠比率 や草本植生の生育型とそれぞれ密接な関係があった。以上の結果から淡水湿地におけるアメンボ類の 生息環境保全において配慮すべき要件を造園的な見地から議論した。
\end{abstract}

1.はじめに

近年, 生物の生息に配慮した淡水湿地環境整備の必要性が広く 認識され，動物の生息と環境条件との関係が詳細に調査されてい る ${ }^{122 / 33}$ 。その結果, 動物の生息場所として具備すべき環境条件を 満たした湿地環境の整備が積極的に行われつつある ${ }^{4) 5}$ 。昆虫類で は，ホタル類やトンボ類など一部の種を対象にそうした試みがな されている ${ }^{67 \eta}$ 。トンボ類は, 成虫が湿地周辺の森林などの広い面 積の陸域をも生息空間とするため，水域と陸域を一体化した環境 の総合的な生物指標として, 特に重視される傾向にある ${ }^{8)}$ 。しか し, これらの昆虫類は, 幼虫が水中で生活し, 成虫が自由飛翔す ることで共通しており，生活環の大部分を水面や水中で経過する 昆虫類の生息環境整備や保全に関する研究例 ${ }^{9}: 10$ は少ない。

そこで本研究では, 淡水湿地の水面上を主要な生息場所とする アメンボ類に着目し，その生息環境保全を通して淡水湿地の環境 を整備するための指針を具体化する目的で，淡水湿地の環境条件 とアメンボ類の生息状況との関係について検討した。アメンボ類 の生息湿地に関する記録には，「開放的な」，「㯺蒼とした」，「小 規模な」といった抽象的な表現が多(1112)。しかし実際の湿地環 境の整備に扔いては, 湿地の規模や配置, 周辺土地利用, 育成誘 導すべき植牛, 樹木の伐採の程度, 汀線部の造形などに関する, より具体的な情報および施工計画方針が必要とされる。したがっ て本研究では，まず野外の湿地において，アメンボ類の生息に影 響を及ぼすと思われる湿地の水面面積, 周辺の土地利用, 湿地内 の樹冠被率，草本植生の生育型と植被率，ならびに汀線部周辺の 物理的組成を調查し，これらとアメンボ類の生息状況との関係に ついて検討した。さらに，湿地におけるアメンボ類の安定発生に 不可欠な産卵場所に特に着目し，異なる産卵基質に対する選択性 や水面に対する産卵場所の位置関係を室内実験によって明らかに した。

本研究ではナミアメンボAquarius paludum paludum, ヒメ アメンボGerris latiabdominis, 八ネナシアメンボGerris nepalensis, ヤスマッアメンボGerris insularis, コセアカアメ ンボGerris gracilicornisの 5 種の中型アメンボ類を対象とした。 調査対象地においてヤスマッアメンボと八ネナシアメンボは準絶 滅危惧種に指定されている ${ }^{(3) 14)}$ 。

\section{2. 方法}

\section{(1) 野外調查}

2000 年および 2001 年の 4 月初旬から 6 月初旬に, 大阪府岬町, ならびに和歌山県和歌山市, 海南市, 橋本市および貴志川町から 選出した 70 の淡水湿地を対象に, 以下の調查を行った。なお, 調査対象とした淡水湿地は, 池 (55 か所), 水田 1 筆 ( 6 か所), および水たまり（９か所）とし，水路や河川などの流水域は除外 した。調査は, 上記期間中にそれぞれの淡水湿地において 2 回実 施した。

(i) 湿地面積

2500 分の 1 地形図を用いて調査対象湿地の水面面積を算出し た。地図に記載のない小規模な湿地は, 踏査時に測量して水深 1 $\mathrm{mm}$ 以上の部分の水面面積を算出した。

(ii）土地利用状況

調查対象湿地の水面全体を取り囲んだ最小面積となる四角形の 重心点を湿地の中心之する半径 $150 \mathrm{~m}$ 冈内の土地利用状況を, 2500 分の 1 地形図を用いて調査した。土地利用は, 樹林地, 市 街地, 草地, 樹園地, 畑地, 水田, 対象湿地と水田を除いた水面, およびその他（土地利用使途不明）の８区分とした。本文中では 樹林地㧍よび市街地の比率をそれぞれ樹林地摔, 市街地摔として 表記した。

\section{(iii）アメンボ類の種組成}

調查対象湿地ごとに, 生息するアメンボの種を以下の方法で調 查した。1人または 2 人の観察者が湿地外周を 1 周して, 水生網 を用いた見つけ捕り法で湿地内のアメンボ類を 10 分間以上採集 し，外部形態に基づいて同定した。ただし，水生網の使用が不可 能な場所では, 汀線から $3 \mathrm{~m}$ 以内の水面上に生息するアメンボ類 を目視で同定した。調查地で 2 回の調査を通じて 5 匹以上の成虫 個体の生息を確認した種を，調查地における生息種とした。

(iv) 樹冠被率, 植被率, 汀線構造

調查対象湿地において, 樹高 $1 \mathrm{~m}$ 以上の木本植生の枝葉が水面 を被う割合を樹冠被率, 水中に生育する草本植物の水面上の茎葉 が水面を被う割合を植被率とし，それぞれ目視によって調查した。 草本植生はその生育型によって以下の 3 タイプに類別し, 植被率 をそれぞれ調査した；

•和歌山大学大学院システム工学研究科 **和歌山大学システム工学部 


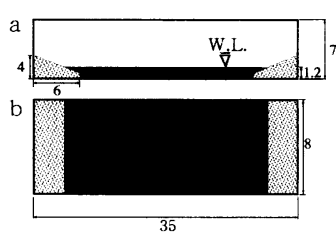

図-1 産卵基質実験のため の飼育容器

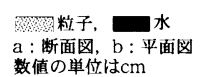

(1)浮葉植物：ヒシ, スイレン, ジュンサイなど浮葉を有する植物,

(2)低茎植物：キシュウスズメノヒエなど水面から植物体上端まで の高さが $30 \mathrm{~cm}$ 末満の植物,

(3)高茎植物：ヨシやガマなど水面から植物体上端までの高さが $30 \mathrm{~cm}$ 以上の植物。

汀線構造については, 汀線周辺の構造物を土砂とコンクリート に大別し，その存否を調查した。な抢石組みはコンクリートに類 別した。

\section{（2）室内実験}

\section{(i) 供試虫}

2000 年と 2001 年の 4 月初旬から 5 月初旬にかけて和歌山県内 の湿地で採集した各種アメンボ個体を供試虫として，採集後 24 時間以内に以下の飼育実験を開始した。飼育容器には雌雄 1 対を 収容し, 慨としてニクバエの幼虫を雌雄一対に毎日 1 匹ずつ与え た。

\section{（ii）産卵基質の物理的組成に対する選択性}

ヤスマッアメンボ，コセアカアメンボ，ナミアメンボ，ヒメア メンボ执よび八ネナシアメンボの 5 種について，それぞれ 10 対 を温度 $20^{\circ} \mathrm{C}$, 明期 15 時間一暗期 9 時間（以下 $15 \mathrm{~L}-9 \mathrm{D}$ と略記） の日長条件で 10 日間飼育した。飼育容器には最深部の水深が 0 . $5 \mathrm{~cm}$ となるように水をはった内径 $12 \mathrm{~cm}$, 高さ $5 \mathrm{~cm}$ の透明の円筒形 容器を用い,これに2 種の産卵基質を入れた。産卵基質には, 面 構造を想定した木片 $(1 \mathrm{~cm} \times 6 \mathrm{~cm} \times 0.9 \mathrm{~cm})$ と，間隙構造を想定 したスポンジ（ $3 \mathrm{~cm} \times 4 \mathrm{~cm} \times 0.9 \mathrm{~cm} ）$ を用いた。各基質は毎日新 たなものと交換することとし，その際に産下された卵を数えた。 調査期間を通じてそれぞれの基質に産下された合計卵数の比較に よって，種ごとの産卵基質選択性を検討した。

（iii）産卵基質の大きさに対する選択性

ヤスマッアメンボ，コセアカアメンボ，ナミアメンボ，ヒメア メンボの 4 種を $20^{\circ} \mathrm{C}, 15 \mathrm{~L}-9 \mathrm{D}$ の条件で 10 日間飼育した。飼育 容器は長辺 $35 \mathrm{~cm}$, 短辺 $8 \mathrm{~cm}$, 高さ $5 \mathrm{~cm}$ の半透明の直方体容器之 し，これに最深部の水深が $1.2 \mathrm{~cm}$ になるように水をはった。さら に産卵基質として, 粒径の異なる 2 種の白色の球形ジルコニア粒 子を, 図 1 に示すように, 容器の雨端に約 $20^{\circ}$ の公配となるよ うに配置した。各容器には, 粒径が $1 \mathrm{~mm}$ 之 $3 \mathrm{~mm}, 3 \mathrm{~mm}$ 之 $10 \mathrm{~mm}$ らびに $1 \mathrm{~mm}$ と $10 \mathrm{~mm}$ の粒子を組み合わせて配置し，各種アメンボ の供試数はそれぞれの粒径粒子の組み合わせにつき 4 対, 4 対, 抢よび 3 対とした。粒子は毎日水で洗浄し，その際に産下された 卵を数えた。調査期間を通じて各粒径粒子に産下された合計卯数 の比較によって，産卵基質に対する選択性を検討した。

（iv）産卵場所の水面に対する位置関係

ヤスマッアメンボ，コセアカアメンボ，ナミアメンボ，ヒメア メンボ，八ネナシアメンボの 5 種について，それぞれ 5 対を室内 条件（気温 $25 \pm 2{ }^{\circ} \mathrm{C}$, 日長無管理）で 5 日間飼育した。飼育容 器には, 長辺 $22 \mathrm{~cm}$, 短辺 $8 \mathrm{~cm}$, 高さ $7 \mathrm{~cm}$ 半透明の容器を用い, 水深は約 $3 \mathrm{~cm}$ とした。図 2 に示すように, 容器の片側に土砂斜面
表ー1 異なる水面面積を有する各種アメンボの生息湿地数およ び非生息湿地数

\begin{tabular}{|c|c|c|c|c|c|c|c|}
\hline 湿地水面面棋 $\mathrm{S}\left(\mathrm{m}^{2}\right)$ & $0<\mathrm{S} \leq 10$ & $75<S \leq 250$ & $250<S \leqq 500$ & $500<\mathrm{S} \leqq 250$ & $2500<S \leqq 100$ & $10000<S \leqq 40000$ & 計 \\
\hline 全調査湿地数 & 9 & 9 & 9 & 27 & 8 & 8 & 70 \\
\hline ヤスマツ| & $5(50.0)$ & $2(20.0)$ & $3(30.0)$ & $0(0.0)$ & $0(0.0)$ & $0(0.0)$ & 10 \\
\hline コセアカ生鬼福地 & $7(77.8)$ & $0(0.0)$ & $2(22.2)$ & $0(0.0)$ & $0(0.0)$ & $0(0.0)$ & 9 \\
\hline ナミ生 & $(0.0)$ & $9(26.5)$ & 2( & $14(41.2)$ & $4(11.8)$ & $5(14.7)$ & 34 \\
\hline 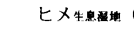 & $0(0.0)$ & $3(18.8)$ & $1(6.2)$ & $9(56.2)$ & $0(0.0)$ & $3(18.8)$ & 16 \\
\hline ハネナシ生是福地 & $0(0.0)$ & $2(12.5)$ & $2(12.5)$ & $6(37.4)$ & $1(6.3)$ & $5(31.3)$ & 16 \\
\hline 非生舫淁地 & $0(0.0)$ & $0(0.0)$ & $6(42.9)$ & $10(42.9)$ & $4(19.0)$ & $3(14.2)$ & 21 \\
\hline
\end{tabular}

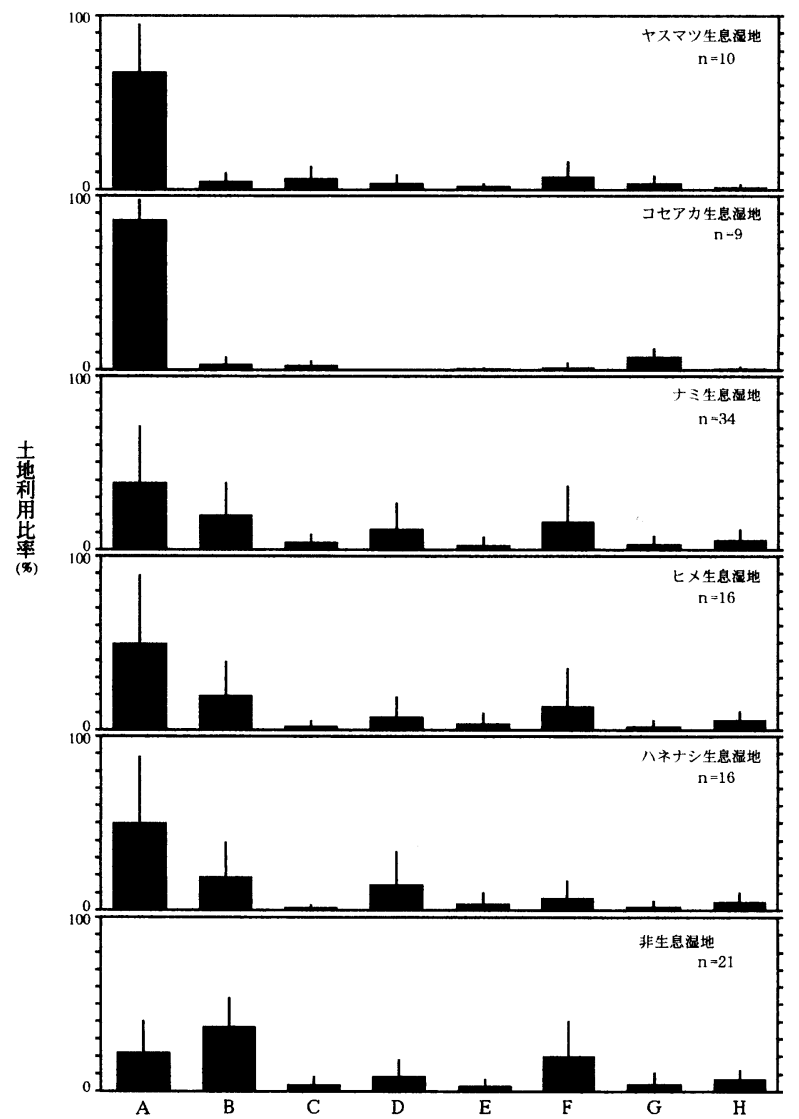

図ー3 各種アメンボの生息湿地および非生息湿地周辺の土地利 用比率

A : 樹林地, B : 市街地, C : 草地, D : 樹園地, E : 畑地, $\mathrm{F}$ : 水田, $\mathrm{G}$ : 水面, $\mathrm{H}$ : その他 縦線は䄅準偏差を示す

を形成し，それを4つの区間に区切った。飼育終了後，土砂を区 間每に取り出し, 最深部の水深が $1 \mathrm{~cm}$ 以下になるように水をはっ た内径 $12 \mathrm{~cm}$, 高さ $5 \mathrm{~cm}$ の透明の円筒形容器に入れ, 室内条件で 20 日間静置し, 粰化幼虫を得た。各区間ごとの合計卯化幼虫数 の比較によって, 種ごとの主要な産卵場所を検討した。

\section{3. 結果}

\section{（1）水面面積と生息種の関係}

表 1 に湿地水面面積と生息種との関係を示した。10 $\mathrm{m}^{2}$ 以下の湿 地には，ヤスマッアメンボとコセアカアメンボの 2 種が生息し, 他の 3 種の生息は確認されなかった。 $75 \mathrm{~m}^{2}$ から $500 \mathrm{~m}^{2}$ の湿地には

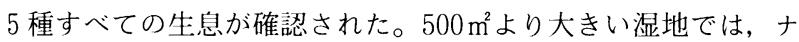
ミアメンボ，ヒメアメンボおよび八ネナシアメンボが高頻度で出 


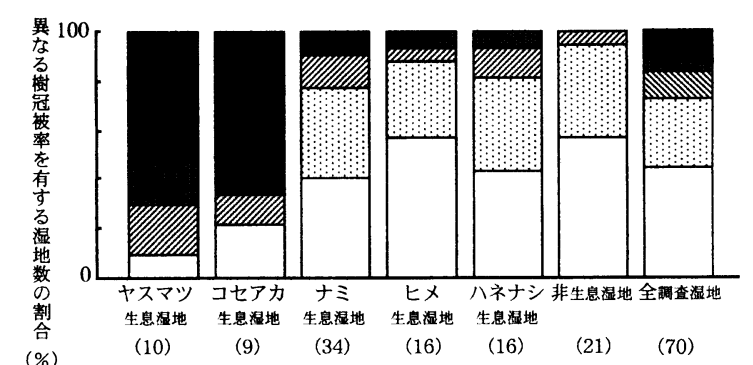

図-4 湿地水面上の樹冠被率とアメンボ類の生息状況との関係

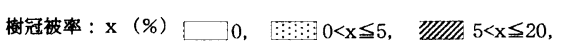

（）内の数字は龧地数を示寸

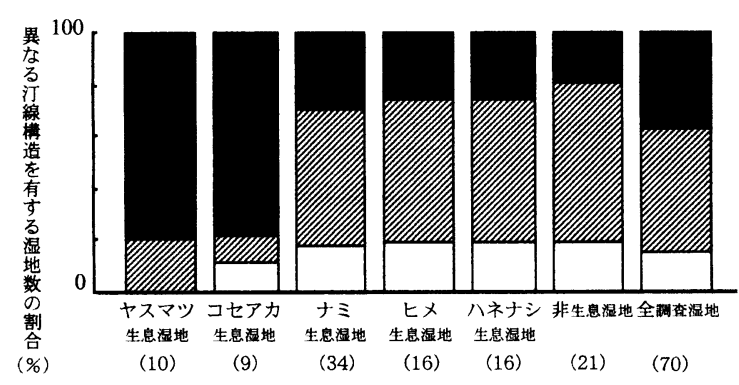

図ー6 汀線構造とアメンボ類の生息状況との関係

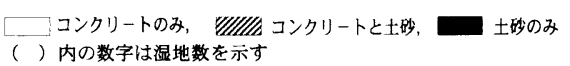

現したが, ヤスマッアメンボとコセアカアメンボは出現しなかっ た。

\section{（2）周辺土地利用と生息種の関係}

湿地周辺の土地利用と生息種との関係を図 3 に示した。土地利 用率は，樹林地と市街地の占める割合が全調查湿地周辺において 相対的に高かった。各種アメンボ生息湿地周辺の樹林地率と非生 息湿地周辺の樹林地率を比べると，非生息湿地周辺の樹林地率は $21.6 \pm 18.4 \%$ (平均士標準偏差) であったのに対し，ヤスマッア メンボ生息湿地周辺では $76.2 \pm 27.1 \%$ ，コセアカアメンボ生息湿 地周辺では $85.8 \pm 11.5 \%$ ，および八ネナシアメンボ生息湿地周辺 では 49.5 $338.4 \%$ であり，非生息湿地周辺の樹林地率に比へ高かっ た。(Mann-Whitney の U 検定，それぞれ $p \leqq 0.002 ， 0.001$ ， 0.040)。ナミアメンボ生息湿地周辺およびヒメアメンボ生息湿地 周辺の樹林地率と非生息湿地周辺の樹林地率の間に有意差は認め

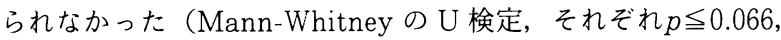
0.060)。

非生息湿地周辺の市街地率と各種アメンボ生息湿地周辺の市街 地率を比べると，非生息湿地周辺では $36.6 \pm 18.4 \%$ であったのに 対し, ヤスマッアメンボ生息湿地周辺で $4.6 \pm 4.8 \%$, コセアカア メンボ生息湿地周辺で $2.5 \pm 4.4 \%$ ，ナミアメンボ生息湿地周辺で $19.7 \pm 18.4 \%$ ，ヒメアメンボ生息湿地周辺で $19.2 \pm 19.7 \%$ ，およ び八ネナシアメンボ生息湿地周辺では $18.7 \pm 19.9 \%$ で，いずれも 非生息湿地周辺の市街地率と比べて低かった（Mann-Whitney の U 検定，それぞれ $p \leqq 0.001 ， 0.001 ， 0.003 ， 0.010 ， 0.009) 。$

\section{（3）樹冠被率と生息種の関係}

図 4 に水面上の樹冠被率と生息種の関係を示した。 $5 \%$ 以上の 樹冠被率を有する湿地の割合は, ヤスマッアメンボで $90 \%$, コ セアカアメンボで $79 \%$ であったのに対し，ナミアメンボ，ヒメ アメンボ抢よびハネナシアメンボ生息湿地ではそれぞれ $25 \%$ 以 下にとどまった。全調査湿地に占める $50 \%$ 以上の樹冠被率を有 する湿地の割合は $15 \%$ と低かったが，ヤスマッアメンボの生息

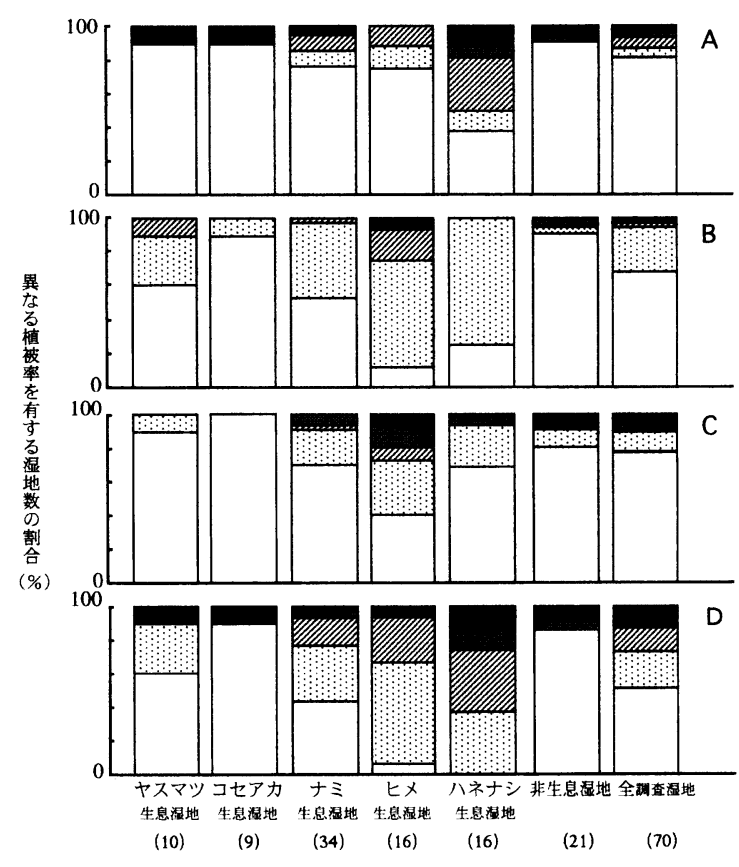

図ー 5 湿地内の草本植生とアメンボ類の生息状況との関係

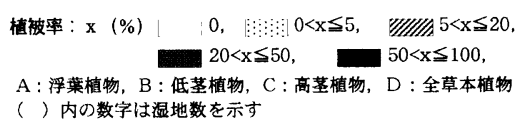

湿地の $50 \%$, コセアカアメンボの生息湿地の $68 \%$ が，50\%以上 の樹冠被率を有した。

\section{（4）植生の生育型および植被率と生息種の関係}

図 5 に水面上の草本植生の生育型別植被率と生息種との関係を 示した。浮葉植物が生育する湿地の割合は, 全調査湿地のわずか 18\%であったのに対し，八ネナシアメンボの生息する湿地の 64 \%で生育が確認された。このうち，5\%以上の植被率を有する湿 地の割合は約 $80 \%$ であった。

低茎植物の生育する湿地の割合は, 全調査湿地のわずか $33 \%$ であったのに対し，ヒメアメンボの生息する湿地の $90 \%$, 八ネ ナシアメンボの生息する湿地の $76 \%$ で生育が確認された。低茎 植物の植被率は, ヒメアメンボの生息湿地に扔いて比較的高く, $5 \%$ 以上の植被率を有する湿地の割合は全体の $28 \%$ であった。

高茎植物の生育する湿地の割合は, 全調査湿地のわずか $23 \%$ であったのに対し，ヒメアメンボの生息する湿地の $60 \%$ で生育 が確認された。このうち $5 \%$ 以上の植被率を有する湿地の占める 割合は全体の $40 \%$ であった。湿地内に生育する全草本植生の植 被率は, 八ネナシアメンボの生息する全湿地, ヒメアメンボの生 息する湿地の $92 \%$ ，ナミアメンボの生息する湿地の $58 \%$ で生育 が確認された。全草本植物の植被率は八ネナシアメンボの生息湿 地において比較的高く， $5 \%$ 以上の植被率を有する湿地の占める 割合は全体の $62 \%$ であった。

\section{（5）汀線構造と生息種の関係}

図 6 に汀線構造と生息種との関係を示した。ヤスマッアメンボ とコセアカアメンボの生息湿地の $80 \%$ は汀線構造が土砂であっ たが,ナミアメンボ，ヒメアメンボおよび八ネナシアメンボの生 息湿地において汀線が土砂であった湿地は全体の 30\%以下にと どまった。

\section{（6）産卵基質の物理的組成に対する選択性}

図 7 に, 物理的組成の異なる 2 種の産卵基質に対する各種アメ ンボの選択性実験の結果を示した。ナミアメンボでは全ての卵が 


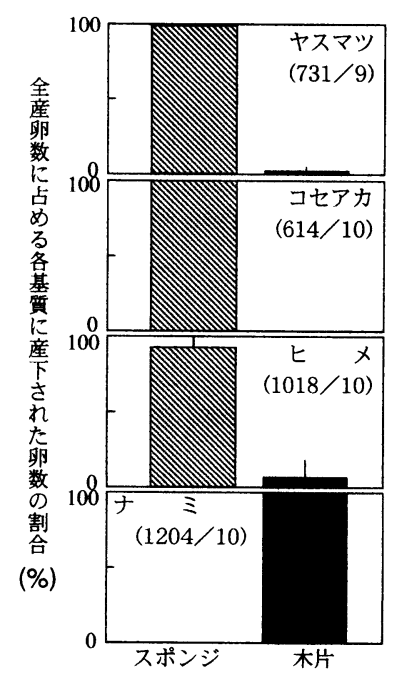

図-7 全産卵数に占める異なる 基質に産下された卵数の 割合

（）の数字は， (全供試数における全産卵数 一全供試対数）を示す 綎線は標準偏差を示す

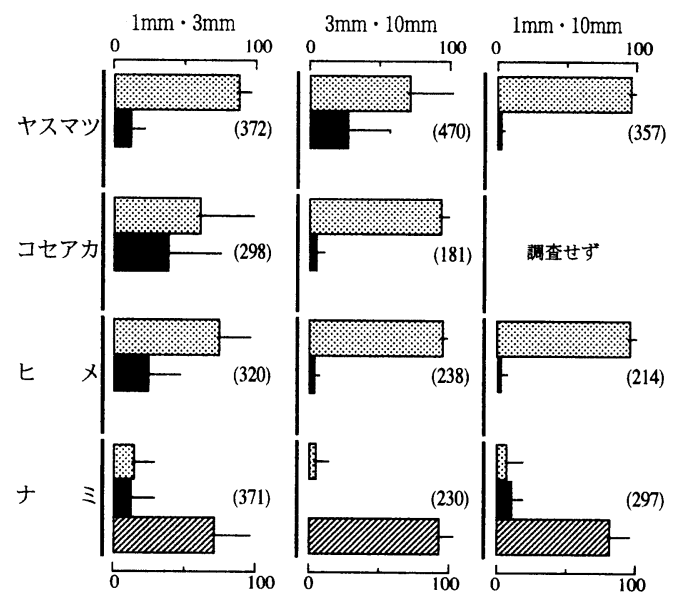

全卵数に占める各粒子に産下された卵数の割合 $(\%)$

図-8 全産卵数に占める異なる直径の粒子に産下さ れた卵数の割合

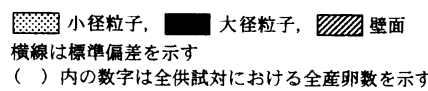

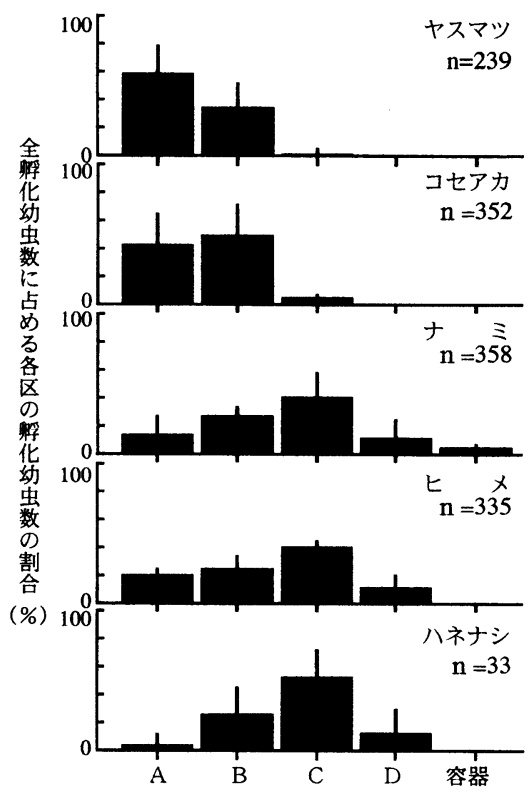

図-9 汀線との位置関係の異なる場所に 産下された卵から睬化した幼虫数 の割合

A〜Dの区名は図ー2に示した $\mathrm{n}$ は全供試対における全哹化数を示す 綐線は標準偏差を示す
木片上に産下された。これに対し，コセアカアメンボでは $100 \%$, ヤスマッアメンボでは $91 \%$ ，ヒメアメンボでは $86 \%$ の卵がスポ ンジに産下された。八ネナシアメンボはどちらの基質にも産卵し なかった。

\section{（7）産卵基質の大きさに対する選択性}

図 8 に各種アメンボにおける異なる粒径の粒子に対する産卵選 択性実験の結果を示した。ヤスマッアメンボでは, 粒径 $1 \mathrm{~mm}$ と 3 $\mathrm{mm}$ の組み合わせの場合, $1 \mathrm{~mm}$ の粒子に産下された卵数の方が多かっ た（Mann-Whitneyの U 検定， $p=0.002) 。 3 \mathrm{~mm}$ と 10mmの組み合 わせでは，両者に産下された卵数に有意差は認められなかった (Mann-Whitney の U 検定, $p=0.149$ )。 $1 \mathrm{~mm}$ 之 $10 \mathrm{~mm}$ の組み合わ せでは, $1 \mathrm{~mm}$ に産下された卵数が比較的多い傾向があった（供試 対数が少ないため検定は行わなかった)。

コセアカアメンボでは, $1 \mathrm{~mm}$ と $3 \mathrm{~mm}$ の組み合わせの場合には, 有意差は認められなかった（Mann-Whitneyの $\mathrm{U}$ 検定, $p$ $=0.602 ）$ が， $3 \mathrm{~mm}$ と $10 \mathrm{~mm}$ の組み合わせでは， $3 \mathrm{~mm}$ に産下された 卵数の方が多かった（Mann-WhitneyのU 検定, $p=0.020) 。$

ヒメアメンボでは, $1 \mathrm{~mm}$ と $3 \mathrm{~mm}$ の組み合わせの場合には有意差 は認められなかった（Mann-WhitneyのU 検定， $p=0.148 ） か ゙$, $3 \mathrm{~mm}$ と $10 \mathrm{~mm}$ の組み合わせでは, $3 \mathrm{~mm}$ に産下された卵数の方が多 かった（Mann-Whitneyの U 検定， $p=0.049$ )。また, $1 \mathrm{~mm}$ と 10 $\mathrm{mm}$ の組み合わせでは $1 \mathrm{~mm}$ に産下された卵数が比較的多い傾向があっ た（供試対数が少ないため検定は行わなかった）。

ナミアメンボでは, いずれの粒径粒子の組み合わせにおいても, 壁面に産下された卵数が最も多く，粒径の大きさに対する選択性 は不明確であった。

\section{（8）産卵場所の水面に対する位置関係}

図 9 に各種アメンボにおける産卵場所の水面に対する位置関係 を示した。ヤスマッアメンボとコセアカアメンボでは，区間 A と 区間 $\mathrm{B}$ における孵化幼虫の割合が約 9 割で，区間 $\mathrm{C}$ における脬化 幼虫の割合は全体の 1 割程度に止まった。区間Dにおける粰化数 は2 種ともに0であった。これに対し，ナミアメンボ，ヒメアメ
ンボおよびハネナシアメンボでは，区間Cにおける孵化幼虫の割 合が最も高く, 全体の約 4 割から 5 割を占めた。また，ヤスマッ アメンボとコセアカアメンボの粰化数が 0 であった区間Dにおい ても,これら 3 種では全体の 1 割程度の卯孚化幼虫が確認された。

\section{4. 考察}

ヤスマッアメンボとコセアカアメンボの 2 種はそれぞれ周辺土 地利用比率で $40 \%$ 以上，70\%以上の樹林地を有する湿地でのみ 見られ，他の 3 種に比べて周辺の樹林地率が高い湿地を生息空間 とする傾向の強いことが明らかになった。また,これら2種は水 面面積が $500 \mathrm{~m}^{2}$ 未満の湿地でのみ見られたが，ナミアメンボ， ヒ メアメンボ, 八ネナシアメンボの 3 種はこれより大きな規模の湿 地にも高率で出現した。さらに，これら 3 種はヤスマッアメンボ とコセアカアメンボの 2 種が生息する水面面積が $10 \mathrm{~m}^{2}$ 末満の湿 地では確認できなかった。以上の結果から, ヤスマッアメンボと コセアカアメンボの 2 種の生息可能性は, 湿地周辺の樹林地率が それぞれ 40\%と $70 \%$ より高く，少なくとも水面面積が $500 \mathrm{~m}^{2}$ 末 満の小規模な湿地が有する環境条件に依存していることを示唆し ている。また，これら 2 種の生息湿地の 8 割以上で樹冠被率が 5 $\%$ より高く, 5 割以上の生息湿地で樹冠被率が $50 \%$ より高かっ た。これに対し，他 3 種の生息湿地の 9 割以上で樹冠被摔が 50 \%以下で， 7 割以上の生息湿地で樹冠被率が $5 \%$ 以下であった。 このことから, ヤスマッアメンボとコセアカアメンボの 2 種は, 他の 3 種に比べ, 高い樹冠被率を有する湿地に生息する傾向が見 られた。ヤスマッアメンボとコセアカアメンボを含むコセアカア メンボ亜属の種は，その他 3 種のアメンボを含むヒメアメンボ属 の中では比較的小さな水域に生息し, その分布が周辺環境の变化 の影響を受けやすいという近年の見解 ${ }^{15)}$ と矛盾しないように思わ れる。

樹林地内の小規模湿地は，樹木伐採や地形改変に伴う湧水の枯 渇, ならびに埋め立てや土砂の流入堆積によって近年減少する傾 向にあると考えられるため，これが，ヤスマッアメンボが準絶滅 
危惧種に選定されるに至った要因のひとつと考えることができる。 ヤスマッアメンボとコセアカアメンボが高率で生息する湿地が有 する高い周辺樹林地率, 小面積の水面, および水面上の高い樹冠 被率の 3 条件は相互に密接な関係をむって満たされるため, 個々 の条件がそれぞれ単独でどれほど強い生息制限要因として機能し ているかは現状では不明である。ただし, 水面面積が $500 \mathrm{~m}^{2}$ 以上 であっても周辺の樹林地率が $40 \%$ 以上の湿地には, 汀線周辺で 樹冠被率の極めて高い空間に生息するヤスマッアメンボとコセア カアメンボの生息条件を満たす環境が出現するように思われる。

だが, 実際には図 10 に示すように, 本研究で調査した水面面積 $10000 \mathrm{~m}^{2}$ 以上の湿地の約 5 割が周辺土地利用率で $40 \%$ 以上の樹林 地率を有していたにも関わらず，2種の生息は全く確認されなかっ た。このことから，少なくとも湿地周辺の樹林地率や水面上の樹 冠が直接的にこれら 2 種の生息環境を規定する要因ではないと推 察できる。現時点では, これら 2 種の保全には, 樹林地内に存在 する樹冠被率の高い小規模湿地を維持するとともに, 樹林地内に 樹冠被率の高い湿地を創出または復元するといった配慮が求めら れるといえよう。

それに対して, その他 3 種の生息湿地は, 樹冠被率, 水面面積 および周辺土地利用率の相違によって明確に区別されなかった。 したがってこれら 3 種の生息環境は, より低い樹冠被率, より広 い水面面積を備えた湿地であり, 特定の周辺土地利用率とは密接 な関係を持たないということができる。しかし，以下に述べるよ うに, これら 3 種の生息環境は湿地内の草本植生の生育型および その植被率との関係によって明確に特徴づけられた。

ヒメアメンボの生息する湿地の 6 割以上が低茥植物または高茥 植物の生育する湿地で, 八ネナシアメンボの生息する湿地の 6 割 以上が浮葉植物または低茎植物の生育する湿地であった。さらに, ヒメアメンボの生息湿地のうち, 浮葉植物の生育する湿地は 2 割 程度と低かったのに対し, 八ネナシアメンボの生息湿地のうち浮 葉植物の生育する湿地が約 6 割と高かった。このことから 2 種の 間には, 異なる生育型の草本植物の生育之密接な関連をもつ, 微 環境（光, 風, 波, 水面間隙など）に対する選好性に違いがある と考えられる。そして，ヒメアメンボと八ネナシアメンボの生息 には草本植生のあることが必要条件に近く，八ネナシアメンボは ヒメアメンボよりも浮葉植物の植被率が高い湿地に相対的に強く 依存する傾向のあることが示唆された。ハネナシアメンボは準絶 滅危惧種に選定されているが, その保全のためには浮葉植物の植 被率を高く誘導することが効果的であると考えることができる。

これまで議論したように, 本研究の対象とした 5 種アメンボ類 個々の特異的な生息環境は, 湿地周辺の樹木㧊よび草本, ならび に水面面積によって規定されることが明らかになった。外国産の 数種アメンボ類においては, 植生構造に対する選択性の相違は, 水面の波や風に対する耐性や採䬹場所の種間差異を反映している ことが指摘されている ${ }^{1617)}$ 。本研究で対象とした 5 種アメンボ類 においては, 生息場所の植生や水面面積の差異が, 水面の波, な らびに水面上および飛翔高度付近の空中の風に対する耐性や定位 の差異を反映しているものと考えることができるが, その詳細の 解明は今後の課題である。

湿地の汀線部周辺の構造と生息種の調査からは, ヤスマッアメ ンボの全生息湿地とコセアカアメンボの大部分の生息湿地で, 汀 線部周辺に土砂を有することが明らかになった。特にこれら 2 種 では, 生息湿地の約 8 割の汀線部が土砂のみであり, 全調查湿地 で汀線部が土砂のみであった湿地の割合（約 4 割）よりも顕著に 高かった。ただし, 図 11 に示すように, 本調查ではこれら 2 種 が出現した $40 \%$ 以上の樹林地率を有する湿地環境において, 汀 線がコンクリート構造であった湿地は 1 例のみであり,これら 2 種の生息環境条件として湿地汀線部の土砂を必要条件と考えるこ

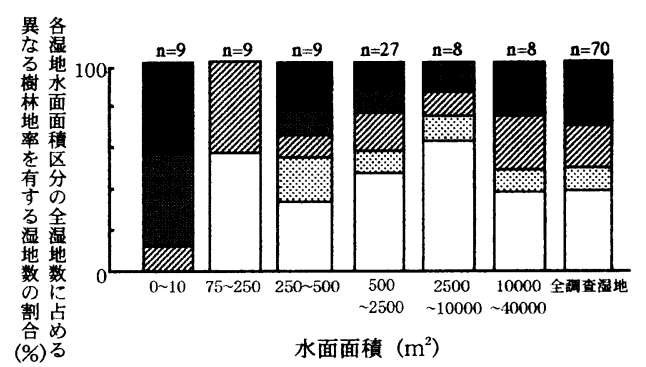

図-10 湿地周辺の樹林地率と湿地水面面積との関係
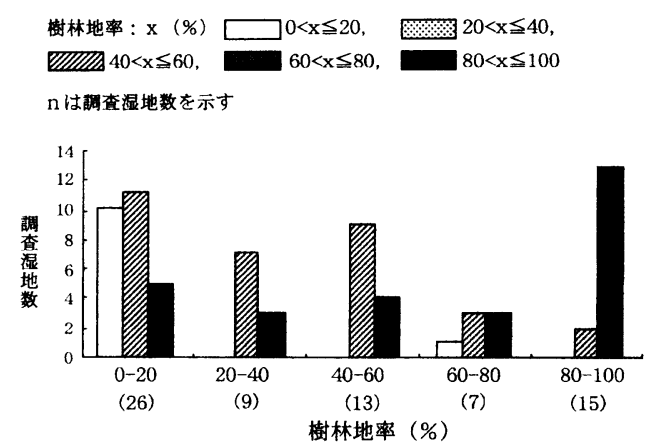

図一11 汀線構造別にみた異なる樹林地率を有する湿地数 （）内の数字は各樹林地率を有する湿地の全調查数を示す

とはできない。

しかしながら, 汀線周辺が土砂である飼育装置内でアメンボ類 を飼育して，水面に対する産卵位置の位置関係を調查したところ， ナミアメンボ, ヒメアメンボ拈よ゙八ネナシアメンボでは, 主と して汀線部付近の土砂を産卵場所としたのに対し, ヤスマッアメ ンボとコセアカアメンボは汀線より上部の陸域を主たる産卵場所 として選択することが明らかになった。したがって, これら2 種 が野外において汀線部周辺に土砂のある湿地を主要な生息場所と していたことは, 陸域の土砂が主な産卵基質として機能している ことを強く示唆する。これら 2 種では他の種よりあ生息湿地の草 本植生の植被率が概亦低かったこともこれと矛盾しない。したがっ て, これら 2 種の保全には, 汀線に隣接する陸域に, 一定の勾配 をもって土砂を配置することが必要と推察できる。

また，粒径の異なるジルコニア粒子に対する産卵選好性から， ヤスマッアメンボは $3 \mathrm{~mm}$ 末満の粒径粒子を特異的に選好し, コセ アカアメンボは $10 \mathrm{~mm}$ 末満の粒径粒子を特異的に選好すると解釈 できたことから, 土砂粒子の粒径についての注意を要することが 必要と考えられた。少なくとあ, ヤスマッアメンボの産卵場所に は粒径 $1 \mathrm{~mm}$ 以下の土が多く含まれる陸域が必要であろう。

八ネナシアメンボはスポンジにも木片にも飼育容器壁面にも産 卵せず, 土砂に対する産卵数が他のアメンボの産卵数よりも顕著 に少なかった。本種のすべての生息湿地には低茎および浮葉植物 が生育したことからここれらを産卵基質として利用している可能 性が高い。

ヒメアメンボは, 室内実験ではスポンジ, 相対的に粒径の小さ い粒子および汀線部の土砂に高い産卵選択性を示したが, 野外に おける本種の生息湿地の汀線部周辺には土砂が存在しない場合が 少なからず確認された。本種の生息湿地むハネナシアメンボ生息 湿地と同様に草本植物の生育することが多かったことから, 野外 においては土砂ばかりでなく, 草本植物を産卵場所として利用で きるものと推察できる。

ナミアメンボはスポンジや粒子よりも, 木片や飼育容器の壁面 といった面を産卵場所として選好する程度が明らかに高かった。 これは, 本種が草本の生育しない, 汀線部周辺に土砂のない湿地 
においてす少なからず生息することと符合する。本種はコンクリー 卜張りの堰堤壁面, 水面に存在する落葉落枝や浮遊物など種々の 基質に産卵しているものと推察される。また, ナミアメンボは水 中の構造物の表面にも潜水して産卵することが知られている ${ }^{18)}$ 。 これらのことは, 本調査でナミアメンボが最む普遍に見られたこ とと, 深く関連すると思われる。

\section{5. おわりに}

湖沼, 池, および水田などの淡水湿地，ならびにそこに生息す る生物の保全や利活用を目的とした整備にあたっては, 湿地およ び周辺の環境把握, 湿地規模や数の変更または決定, 湿地の配置, 陸域との境界部分の造形, 植生誘導などといった視点で計画が具 体化するすのと考えられる。整備の対象地域や主目的，ならびに 具体的対象物とする生物や景観要素によって空間整備に求められ る具体的な配慮事項や造園技術は異なるであろうが，上記の視点 にしたがって計画を具体化する過程において, 問題とすべき生物 や景観要素の選定を適切に行うための手続き論, および, 普遍化 可能な手法，ならびに配慮事項や造園技術を確立するための情報 の集積の意義は高いと思われる。

本研究では, 従来の湿地環境整備において主対象物として選定 されることの少なかった水面生活生物に着目し，その生息環境保 全で留意すべき環境構成要因を具体的に整理することを通じて, 淡水湿地の環境を改善するための整備手法を, より普遍化された 視点で確立するための情報を造園学的見地に立って提供すること
を試みた。したがって, 本研究では離島を除く日本列島にほぼ普 遍的に分布し, 採集や同定が容易な 5 種のアメンボを対象として, 湿地の環境整備計画の概要決定や評価の際の高い普遍性や利便性 が得られるよう配慮した。

本研究の成果は以下のように要約される。1）淡水湿地に生息 する止水性アメンボ類の生息環境保全においては, 湿地の水面面 積, 周辺土地利用, 湿地水面上の樹冠および植被, ならびに汀線 部周辺の素材や面積に配慮した計画および施工がなされるべきで ある。2）周辺の樹林地率が $40 \%$ 以上で, 水面面積 $500 \mathrm{~m}^{2}$ 以下の 小規模湿地においては保全対象物としての優先度が比較的高い 2 種アメンボ類の生息可能性が高いため, 計画段階において別段の 配慮が必要である。3)これら 2 種の生息環境整備誘導において は，樹林内に小規模な湿地を確保することが基本となるが，同時 に水面上の樹冠被率を高くするための樹木の育成, ならびに汀線 部から陸域方向に一定以上の土砂状素材の面積を確保することが 必要である。4) その際, コセアカアメンボでは粒径 $3 \mathrm{~mm}$ 程度以 下の粒子を主体とする素材の利用, ヤスマッアメンボでは粒径 1 $\mathrm{mm}$ 程度の粒子を主体とする素材の利用が少なくとも好適であると 考えられる。5）その他の 3 種アメンボは水面面積 $75 \mathrm{~m}^{2}$ 以上の 湿地であれば，生息，または比較的容易に生息を誘導できる。6) このうち，ヒメアメンボと八ネナシアメンボの生息環境整備にお いては, 水面上の草本植生を管理誘導することが主要な配慮事項 となる。7) 後者の生息環境整備においては, 特に浮葉植物や低 荃植物を優占植生とすることが求められる。

\section{引用文献}

1) H.Urabe, and S.Nakano (1999): Linking microhabitat availability and local density of rainbow trout in low-gradient Japanese streem. Ecological Research 14, 341-349

2 ) 大澤啓志・勝野武彦 (2000) : 多摩丘 陵南部におけるシュレーゲルアオガエ ル生息の環境条件の把握と保全に関す る考察：ランドスケープ研究 63(5), $495-500$

3 ）橴江桂子・大場信義・藤井英二郎（19 95）: 三浦半島野比地区におけるゲン ジボタルの成虫個体数に影響を及ぼす 生息環境要因の解析 : ランドスケープ 研究 58(5), 21-24

4 ) 桜井善雄・市川新・土屋十图 (1996): 都市の中に生きた水辺を：信山社出版, $282 \mathrm{pp}$

5 ）杉山恵一（1996）：みんなでっくるビ オトープ入門 : 合同出版, $264 \mathrm{pp}$
6 ) 自然環境復元研究会 (1991) : 自然復 元特集 ホタルの里づくり：信山社サ イテック, 135pp

7 ) 星野雅廣 (1997): 緑の読本 シリーズ 43 特集 トンボ・エコアップ: 緑化環 境情報センター, $100 \mathrm{pp}$

8 ) 田口正男 (1997)：農村環境とビオトー プ トンボの里 アカトンボに見る谷 戸の自然：信山サイテック, $144 \mathrm{pp}$

9 ) 市川憲平 (2000) : タガメビオトープ の試み：ため池の自然 32, 9-14

10）江崎保男 - 田中哲夫（1998）：水辺環 境の保全一生物群集の視点から-: 朝 倉書店, $220 \mathrm{pp}$

11）宮本正一（1961）：日本昆虫分類図説 1 (3), 4-31

12) 今森光彦 (2000)：ヤマケイポケット ガイド 水辺の昆虫：山と渓谷社, $168-$ 175

13）大阪府（2001）: 大阪の自然ガイドブッ ク：農林水産事業振興事業実行委員会,
101

14）和歌山県 (2001)：保全上重要な和歌 山の自然和歌山県レッドデータブック： 和歌山県環境生活総務課, 159

15）立川周二・佐藤光一（1999）：栃木県 のコセアカアメンボ亜属とその分布： Bull. Tochigi Pref. Mus. 16, 31-38

16) Spence, J. R., and G. G. E. Scudder (1980) : Habitats, life cycles, and guild structure of water-striders (Heteroptera: Gerridae) on the Fraser Plateau of British Columbia. Canadian Entomologist 112, 779792

17) Spence, J. R. (1981) : Experimental analysis of microhabitat selection in water-striders (Heteroptera: Gerrid ae). Ecology 62(6), 1505-1514

18）乾寛（2000）：アメンボのふしぎ：ト ンボ出版, $31 \mathrm{pp}$

Summary : We investigated the relationships between five species of water strider (Gerridae) and the environmental conditions in 70 freshwater wetlands in the Kinki district. The environmental conditions measured were phisical structure on/near shoreline, plant coverage on/above water surface, and landcover of adjacent area. Furthermore, the differences in the preference for oviposition substrates and in the oviposition site among the five speceis of water strider were clarified in the laboratory. It was suggested that occurrence of G.insularis and G.gracillicornis were dependent on the relative abundance of woody area surrounding the wetland, the crown coverage above the water surface, and the erath and sand on/near shoreline. On the other hand, occurrence of A.paludum, G.latiabdominis, and G.nepalensis seemed to be dependent on the plant coverage above the water surface, and the grown types of herbs and grasses. Based on these results, we discussed about the direction of improvement of environmental conditions of freshwater wetland for conservation of habitat of gerridae from the viewpoint of landscape architecture. 